\title{
A bridge bełween ACRL and other organizations
}

\author{
By Elaine Coppola, Norma Hervey, and Susanna Bartmann Pathak
}

\section{Reports to ACRL's Professional Liaison Committee}

$\mathbf{T}$ he initial intent of ACRL in establishing the Professional Liaison Committee was to encourage members to offer papers and poster sessions, participate on panels at professional meetings, and/or publish in journals of other professional organizations. For some years in the 1980 s, competitive funds were available to support building stronger links to other groups in higher education.' While funding is no longer available, the committee continues to encourage and monitor liaison activities.

In response to a request from committee chair Barbara Ford (Virginia Commonwealth University), the committee recently received a number of written reports from official ACRL liaisons. The committee believes that their activities are of interest to all ACRL members who, like ACRL president Tom Kirk (Berea College), place importance on networking as a way of sharing our strengths and enhancing our ability to achieve mutual goals.

\section{The ACRL liaison reports}

The Modern Language Association. ACRL has two official liaisons to the Modern Language Association of America (MLA): Susanna Bartmann Pathak (Johns Hopkins University) and William Gargan (Brooklyn College). Among their liaison activities are encouraging ACRL members to join and participate in the MLA; attending the MLA annual conventions and reporting on programs, projects, and other issues at a variety of ALA meetings and on electronic discussions lists when relevant; and participating in the MLA's programs and activities. One special area of participation is with the MLA International Bibliograpby. Several members of ACRL's English and American Literature Discussion Group index for the Bibliograpby and a large group (25+ members) have worked on ACRL's Ad Hoc MLA International Bibliography Scope and Overlap Committee which studies and advises on the coverage of the Bibliography. This cooperative effort has proven so successful that ACRL is being petitioned to establish a permanent discussion group (MLA International Bibliography in Academic Libraries Discussion Group) with an expanded focus. Additionally, many joint members of ACRL and MLA are members of MLA committees, give papers at the annual conventions, and/or publish articles and books in their fields of expertise.

\section{The Coalition for Networked Informa} tion. ACRL liaisons to the Coalition for Net worked Information (CNI) are Thomas Kirk and Noreen Alldredge (California State UniversityHayward). They attend the semiannual meetings of the CNI and prepare a report forCERL News (see News from the Field, page 357 of this issue). As Kirk indicates, CNI focuses on the activities of its membership rather than conducting programs of its own. Thus, its working groups dedicated to areas of effort (e.g., Transformation of Scholarly Communication, Legislation, Teaching and Learning, Modernization of Scholarly Publication, Access to Public Information) are excellent avenues for ACRL involvement. Kirk has worked closely with the Teaching and Learning Working Group that is participating in two projects: 1) the work of 
the ACRL/BIS Emerging Technologies in Instruction Committee on developing models for instruction in the use of the Internet, and 2) a proposal for an invitational conference on the incorporation of networking into teaching and learning activities.

The Association for Asian Studies. William Sheh Wong (University of California-Irvine) is the ACRL liaison to the Association for Asian Studies (AAS). He reports that AAS has three librarians' groups: 1) CEAL: the Committee on East Asian Libraries (159 members, 108 are also ALA members); 2) CONSALD: the Libraries Documentation Committee of South Asian Council (29 members, 7 are also ALA members); and 3) CORMOSEA: the Committee on Research Materials on Southeast Asia (29 members, 5 are also ALA members). In addition, there is an Asian Librarians Liaison Committee (ALL) which includes the chairs of the three librarians' groups and three other individuals. Wong feels there are good opportunities for joint panel proposals and seminar and conference cosponsorships by ACRL and AAS.

The American Association of University

Professors. The American Association of University Professors (AAUP) liaison is Jody Newmyer (Eastern Connecticut State University), who is a member of the AAUP Council. At the November 1993 Council meeting there was consensus for the AAUP to join with other organizations (including ALA) to take a proactive stance in ensuring that a nonprivatized electronic information network dedicated to non-commercial educational uses is maintained.

The American Chemical Society. ACRL liaisons to the American Chemical Society (ACS), Division of Chemical Information, are Arleen Somerville (University of Rochester) and Howard Dess (Rutgers University). Somerville has asked chemistry professor Norman Craig (Oberlin College), a member of ACS' Committee on Professional Training, to write an article for CERL Neres about the impact of journal and Chemical Abstracts cancellations on ACS certification. In addition to her activities on three ACS committees, Somerville has encouraged communication on bibliographic instruction between ACRL's Bibliographic Instruction Section and ACS' Division of Chemical Information and submitted reports on ACS activities to ACRL's Science and Technology Section's electronic newsletter.

The National Forum on Information Literacy. Barbara Ford and Althea Jenkins (ACRL) are ACRL liaisons to the National Forum on Information Literacy. Ford reports that she worked with Patricia Breivik (Towson State University) to prepare an article for American Libraries on information literacy that was published in January 1992, and has submitted another article on information literacy going international. Ford notes that Breivik's involvement with the forum is an excellent example of an academic librarian's involvement with another professional organization which has opened doors to ACRL collaboration.

As these reports show, ACRL liaisons are very active and successful in their activities. The ACRL Professional Liaison Committee is certain that many other librarians, official liaisons or not, are involved with other professional organizations. We are interested in reporting on your activities in future issues of CERL News. We also invite your comments and ideas for future liaison activities. Please contact Susanna Bartmann Pathak, Milton S. Eisenhower Library, The Johns Hopkins University, 3400 N. Charles St., Baltimore, MD 21218; e-mail: SPATHAK@ JHUNIX.HCF.JHU.EDU.

\section{Note}

1. Jacquelyn M. Morris, "Funds for professional activities," CERL News 49 (May 1988): 29192; Louise S. Sherby, "ACRL professional liaison activities," CERL News 50 (April 1989): 287-89.

\section{(INFORMA cont. from page 347)}

log Project; Query by Image Content (QBIC); Simon personal communications manager providing cellular phone, fax, e-mail, cellular pager, address book, calendar and appointment scheduler, calculator, clock, paperless note pad, handwriting and keyboard functions, help functions, and message pager; Images of the French Revolution; Promenade: The National Agricultural Library and University of Pittsburgh Image Database Project; IBM ThinkPad notebook computer with the Trackpoint II pointing device; the Patent Information Access Server (PIAS); and Express Author multimedia authoring tool, with which faculty can create effective courseware quickly, easily, and with no computer programming.

Look for INFORMA incorporated as a track within the IBM Higher Education Executive Conference next spring. 